\title{
Source and distribution of organic matter in surface sediments from mangroves on the island of Itaparica, Bahia/Brazil
}

\author{
Elisângela Costa Santos • Joil José Celino • \\ Vera Lúcia Cancio Souza Santos • \\ José Roberto Bispo De Souza
}

Received: 30 September 2012 / Accepted: 4 June 2013 /Published online: 16 June 2013

(C) Springer Science+Business Media Dordrecht 2013

\begin{abstract}
Elemental analysis and isotopic composition evaluated the impact of human activity at the surface sediments in the largest island of Todos os Santos Bay, northeastern Brazil. Saturated hydrocarbons (n-alkanes and isoprenoids) by gas chromatography coupled with a flame ionization detector and ${ }^{13} \mathrm{C}$ by mass spectrometer were determined from 30 surface sediment samples in mangroves at the Itaparica Island (Bahia-Brazil) in the rainy and dry season. These data, distribution, and ratio of carbon/nitrogen showed a mixture of sources: continental, marine, and anthropogenic ones. From the chromatographic profiles, light oil contamination was observed in the dry regions of Baiacu, Campinas, and Ponta Grossa, while in Jiribatuba it was observed during the rainy season. However, $\delta^{13} \mathrm{C}$ results during dry and rainy season in
\end{abstract}

E. C. Santos $(\bowtie) \cdot$ J. J. Celino

Instituto de Geociências, Núcleo de Estudos Ambientais, Universidade Federal da Bahia,

Rua Barão de Geremoabo, Campus Ondina,

40170-290 Salvador, Bahia, Brazil

e-mail: eliscsantos@yahoo.com.br

V. L. C. S. Santos

Instituto de Química, Universidade Federal da Bahia,

Campus Ondina,

40170-115 Salvador, Bahia, Brazil

J. R. Bispo De Souza

Instituto de Física, Universidade Federal da Bahia,

Rua Barão de Geremoabo s/n,

CEP 40170-115 Salvador, Bahia, Brazil the presence of oil also showed in Misericordia and Cacha Prego districts for both periods and Ponta Grossa during the rainy season. Principal component analysis, using a correlation matrix, revealed the latent relationships among all the surface sediment stations investigated and confirmed our analytical results.

Keywords Saturated hydrocarbons $\cdot \delta^{13} \mathrm{C} \cdot$ Organic carbon $\cdot$ Mangroves $\cdot$ Estuary

\section{Introduction}

In the mangrove ecosystem, tidal power is bland and current velocity is low which favor the intense deposition of fine sediments and organic matter (Rossi and Mattos 2002; Zagatto and Bertoletti 2008).

The chemical composition of sedimentary organic matter may vary depending on the weather on the coast and the contributions of marine and continental organic matter residues (Queiroz and Celino 2008; Pait et al. 2012). The anthropogenic influence on the environment modifies the composition and concentration of organic matter, potentially affecting the local biota (Queiroz and Celino 2008; Ekpo et al. 2012).

Carbon and nitrogen are the two main components of organic matter. The carbon content in the pellet surface depends on a number of factors such as sedimentary characteristics, the rate of microbial degradation, column of water and land ratio of entries (Costa et al. 2011). The organic material from higher plants has low 
nitrogen content and therefore a high carbon/nitrogen $(\mathrm{C} / \mathrm{N})$ ratio. Therefore, high $\mathrm{C} / \mathrm{N}$ ratios in marine sediments indicate a predominantly terrestrial source of organic matter, while sediments rich in marine organic matter have lower $\mathrm{C} / \mathrm{N}$ ratios (Burone et al. 2003; Gonsalves et al. 2011). According to Bordovsky (1965), marine sediments near the river exhibit the highest $\mathrm{C} / \mathrm{N}$ ratios, indicating entry of terrestrial material in the area. The input of inorganic nitrogen from sewage can contribute to the reduction of $\mathrm{C} / \mathrm{N}$ proportion.

The carbon isotope ratio distinguish between sources of sedimentary organic matter, either in marine or terrestrial plants, mainly reflecting the dynamics of assimilation during photosynthesis and the isotopic composition of carbon source (Meyers 1997). According to Mahiques et al. (1999), using the values of $\delta^{13} \mathrm{C}$, based on the subscriptions of different isotopes in $\mathrm{C}_{3}$ plants (higher land plants), and $\mathrm{C}_{4}$ (grass), in benthic organisms, zooplankton, and phytoplankton led to an increasing number of studies and better understanding of sediment dynamics in continental and coastal areas.

Hydrocarbons present in the sediments originate from petroleum inputs, partial combustion of fossil fuels, forest fires, and diagenetic degradation of biogenic precursors (Readman et al. 2002; Killops and Killops 2005; Celino and Queiroz 2006), constitute an important amount of the organic material that reaches the sediments.

Concentrations of total aliphatic hydrocarbons in unpolluted intertidal and estuarine sediments are normally lower than $10 \mu \mathrm{g} \mathrm{g}^{-1}$ (Volkman et al. 1992). In organically enriched sediments, when there is a significant input of n-alkanes derived from higher plants, total aliphatic hydrocarbon concentrations may have reached values up to $100 \mu \mathrm{g} \mathrm{g}^{-1}$ (Venturini et al. 2004).

The positive correlation $(p<0.05)$ between total organic carbon and total aliphatic hydrocarbons could be related to the input of terrestrial plant materials (Venturini et al. 2004) as well as to the input of petroleum products (McGroddy and Farrington 1995).

Preferred Carbon Index evaluates the maturity of thermal oil and may be used to verify the origin of organic matter. Values much higher than 1 indicate a contribution of higher plants which is considered an immature oil; however, values equal to 1 indicate an increasing maturity of oil, thus presenting the presence of oil (Killops and Killops 2005).

$\mathbf{C P I}=\S\left(\left(n-\mathrm{C}_{25}-n-\mathrm{C}_{33} / n-\mathrm{C}_{24}-n-\mathrm{C}_{32}\right)+\left(n-\mathrm{C}_{25}-n-\mathrm{C}_{33} / n-\mathrm{C}_{26}-n-\mathrm{C}_{34}\right)\right)$

(Moldowan et al. 2007)

Todos os Santos Bay, with an area of approximately $927 \mathrm{~km}^{2}$, is the largest on the northeastern Brazilian coast, with an approximate volume of $6.39 \times 10^{9} \mathrm{~m}^{3}$, a medium depth of $6.9 \mathrm{~m}$ and currents with medium speed of $41.0 \mathrm{~cm} \mathrm{~s}^{-1}\left(1.476 \mathrm{~m} \mathrm{~h}^{-1}\right)$. These factors contribute to the low water residence time in the bay, minimizing the effects of the industrial effluents to be discharged into the bay (Lessa et al. 2008).

Since 1950, the area around Todos os Santos Bay (TSB) has been suffering increasing industrialization and exploitation of its natural resources (Queiroz and Celino 2008). Presently, the extraction, transportation, and refinement of petroleum at TSB are the most prominent industrial activities. The Itaparica Island is outside the area of petroleum activities, at the extreme south of TSB (Fig. 1).

Principal component analysis (PCA) reduces the number of variables in the original data set into fewer factors (or principal components) without significant loss in the total variance of the data. The load of each variable in the original data contributes to the major components and allows the grouping of data with similar behaviors (Celino et al. 2012; Praveena et al. 2012).

The aim of this study was to investigate saturated hydrocarbons (n-alkanes and isoprenoids) and stable carbon isotopic $\left(\delta^{13} \mathrm{C}\right)$ composition in the different seasons, in surface sediments samples, from various mangroves of Itaparica Island (Bahia-Brazil), in order to assess their possible origins, especially with respect to contamination from anthropogenic sources.

\section{Materials and methods}

The TSB has two entrances separated by Itaparica Island (Fig. 1). The Itaparica Channel, on the southwest, which presents a smoother topography with an average depth of $10 \mathrm{~m}$ (Lessa et al. 2008). The circulation inside the bay is mostly tidally driven. 

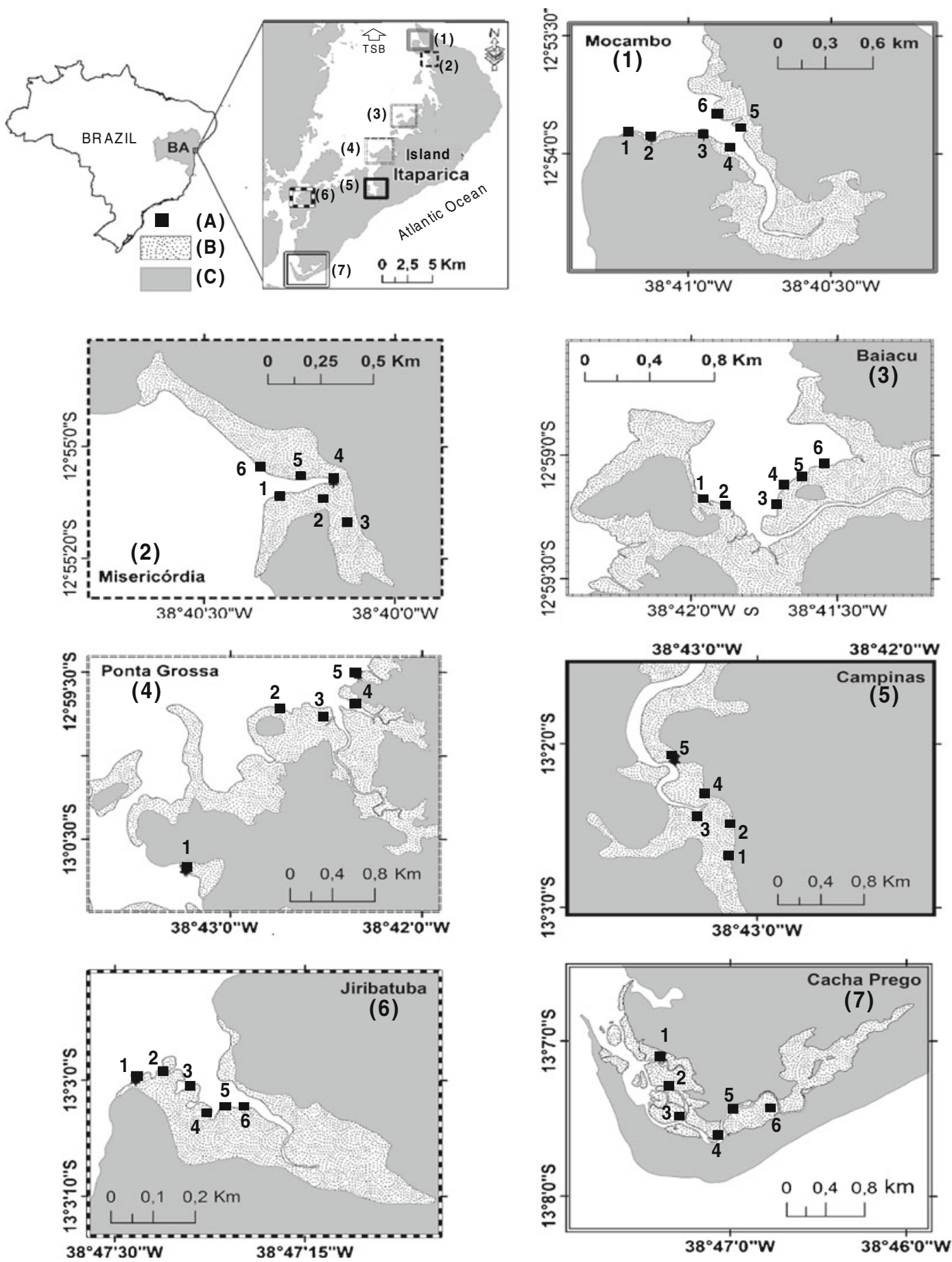

Fig. 1 Map of collecting stations Mocambo, Misericórdia, Baiacu, Cacha Prego, Ponta Grossa, Jiribatuba, and Campinas in Itaparica Island, Bahia, Brazil

During summer, the waters inside the bay have oceanic characteristics, while during winter there is a significant increase in freshwater fluxes (Souza et al. 2011).
The climate is tropical humid, with a 10 -year average mean air temperature of $25.3^{\circ} \mathrm{C}$ close to Salvador, and a 30 -year mean rain fall of about $1,900 \mathrm{~mm} /$ year for the bay area (Lessa et al. 2008). 
Sampling

Surface sediments ( 0.0 to $2.0 \mathrm{~cm}$ depth) were sampled twice (dry and rainy seasons) during low tide at the intertidal zone. Seven stations sampled from the Mocambo (MB), Misericórdia (MD), Baiacu (BI), Ponta Grossa (PG), Campinas (CA), Jiribatuba (JI), and Cacha Prego (CP) (Fig.1). Composite sediment samples, within a $90 \times 90-\mathrm{cm}$ square, were collected from each station along a horizontal transect $(0.1 \mathrm{~km}$ long), at every $10 \mathrm{~m}$, by using a stainless steel spatula and transported to the laboratory in ice boxes $\left(4 \pm 2{ }^{\circ} \mathrm{C}\right)$. Each sediment sample was well mixed and kept frozen until analysis.

Bulk sediment characteristics

pH measurements obtained with a SCHOTT Geräte Handylab 1, L7137A pH meter, by inserting the platinum electrode $(\mathrm{pH})$ directly into the sediment (Berrêdo et al. 2008). The electrode for $\mathrm{pH}$ measurement was periodically calibrated with standard solutions $\mathrm{pH} \mathrm{4,} \mathrm{7,} \mathrm{and} 10$ (NIST). The temperature was measured with a SCHOTT Handylab 1, LF 513T/LF $613 \mathrm{~T}$ portable tag apparatus by inserting the platinum electrode directly into the sediment due to a temperature sensor.

Samples previously lyophilized by L101 Liotop Lyophilizer for $48 \mathrm{~h}$ and homogenized with a stainless steel spatula. Around $12 \mathrm{~g}$ of the sample were transferred to a crucible and brought to the oven at $500{ }^{\circ} \mathrm{C}$ for $5 \mathrm{~h}$ to remove the organic material thereby obtaining a constant weight. Thereafter, the samples transferred to $2.00 \mathrm{~mm}$ (ABNT No. 10), $0.59 \mathrm{~mm}$ (ABNT No. 30), and $0.150 \mathrm{~mm}$ (ABNT No. 100) stainless steel sieves fitted one above the other, keeping the higher mesh above the lower one. After stirring these sieves for $5 \mathrm{~min}$ using a RETSCH AS200 mechanical stirrer, width $1.51 \mathrm{~mm} / \mathrm{g}$, the fraction retained on each sieve was weighed and removed (Embrapa, 1999).

\section{Organic carbon analysis}

Approximately $3 \mathrm{~g}$ of each sample lyophilized and treated with $10 \mathrm{ml}$ of $\mathrm{HCl} 1 \mathrm{~mol} \mathrm{~L}^{-1}$ for carbonates removal. After $24 \mathrm{~h}$, the samples were centrifuged for $1 \mathrm{~min}(3,000 \mathrm{rpm})$ and the supernatant discarded. The procedure repeated until no further effervescence occurred in the sample. The samples washed and centrifuged three times with ultrapure water, dried below $50{ }^{\circ} \mathrm{C}$, and weighed. Each sediment sample (10-12 mg) weighed into a tin capsule, sealed, and then subjected to elemental analysis (Costa et al. 2011). Organic carbon and nitrogen isotope values were determined by elemental analyzer ECS 4010 CHNS-O Analyser Costech Instruments. Isotopic analysis determined by the elemental analyzer coupled to a Finnigan Delta Plus mass spectrometer. The gases used in the product showed high purity $(300 \mathrm{kPa}$ of $\mathrm{He}$ and $\mathrm{O}_{2}$ where $\mathrm{He}$ is the carrier gas). In the equipment, it was used a thermal conductivity detector whose combustion gas used in the samples was $\mathrm{O}_{2}$ at $30 \mathrm{~mL} \mathrm{~min}^{-1}$ for $5 \mathrm{~s}$ and oven operating temperature of $900{ }^{\circ} \mathrm{C}$.

\section{Instrumental analyses}

The methodology used for the extraction of the fraction of hydrocarbons based on Banjo and Nelson (2005). Each sample of sediment previously lyophilized was weighed about $10 \mathrm{~g}$ and subjected to $30 \mathrm{~mL}$ of organic solvents mixture (DCM/hexane-1:1 v/v) in a USC $2800 \mathrm{~A}$ Unique ultrasound bath, frequency $40 \mathrm{kHz}$, for 3 cycles of $10 \mathrm{~min}$ each. The organic extracts obtained were concentrated using a pre-rota-evaporator, then, quantitatively, transferred to a vial and subjected to nitrogen gas stream. The determination of the hydrocarbons performed by gas chromatography coupled with a flame ionization detector (GC/FID, Varian CP3800). The dissolved samples in $n$-hexane and directly injected without flow divider in a gas chromatograph using a DB-5 $30 \mathrm{~m} \times 0.25 \mathrm{~mm} \times 0.25 \mathrm{~mm}$ DB-5 stationary phase column (5\% phenyl, $95 \%$ methyl silicone), with the injector at $280{ }^{\circ} \mathrm{C}$, initial column temperature $50{ }^{\circ} \mathrm{C}$, $1 \mathrm{~min}$ isothermal, $6{ }^{\circ} \mathrm{C} / \mathrm{min}$, heating rate to the final temperature of $310^{\circ} \mathrm{C}$, and $10 \mathrm{~min}$ isothermal.

The individual hydrocarbons (pristane $(\mathrm{P})$, phytane (F), and $n-\mathrm{C}_{10}$ to $n-\mathrm{C}_{40}$ ) were measured in relation to the area of its external standard calibration.

Compound identification and quantification

Total organic carbon (TOC) was measured in triplicate with a standard deviation of less than $1 \%$. Analysis of blank reagent showed that the analysis system and the glass container for extraction were free of contamination. 
Isotopic organic carbon ratios registered in ppm (\%o) and calculated as following:

$\delta^{13} \mathrm{C}(\% \mathrm{o})=\left\{R_{\text {sample }} / R_{\text {standard }}-1\right\} \times 1,000$,

Where $R_{\text {sample }}$ and $R_{\text {standard }}$ are ${ }^{13} \mathrm{C} /{ }^{12} \mathrm{C}$ standard and sample isotopes, respectively. Carbon isotope compositions measured by an international standard of known concentration (PDB-Pee Dee Belemnite). The values of $\left(\delta^{13} \mathrm{C}\right)$ carbon isotopic ratios reported to PDB international rating scale. Reproducibility based on triplicate analysis were $\pm 0.2 \%$ o $(n=6)$.

Quantification was performed using internal standards and the analytical program was conducted under controlled laboratory conditions, following a laboratory quality assurance protocol that includes analysis of reference material (NIST-1941), procedural blanks and participation in international intercalibration exercises.

For the analysis of individual n-alkanes, the limits of detection were on average $9 \times 10$ and $9 \times 10^{-4} \mu \mathrm{g} \mathrm{g}^{-1}$ (dry weight). The limit of quantification (LQM) was $0.10 \mu \mathrm{g} \mathrm{g}^{-1}$ (dry weight).

Since natural samples consist of complex hydrocarbons mixtures, different parameters, in addition to absolute concentrations, were analyzed to evaluate the probable origin (anthropogenic or biogenic) of hydrocarbons.

Statistical analyses

The mean and standard deviation values were calculated. All concentration data prior to statistical analysis were normalized by logarithm $(\log 10)$ transformation. Differences among mangrove stands were analyzed by a parametric one-way analysis of variance (ANOVA). $F$ test was performed to detect any difference between core samples collected.

In order to explore more latent relationships to the investigated stations, PCA was applied to the obtained results. PCAs reduce the scaling of the data and form a smaller set of orthogonal factors of easier interpretation. The principle is to transform the original set of variables in a smaller set of linear combinations, which accounts for the greater part of the variance of the original set. The primary function of this analysis is to reduce the number of variables maintaining the original information as much as possible, so that the variables with similar characteristics grouped into factors (Magalhães et al. 2007).

Statistical tests were performed using the computer software STATISTICA ${ }^{\circledR}$ (StatSoft 1997).

\section{Results and discussion}

Using ANOVA: single factor through $F$ test, it was verified that the $\mathrm{pH}, \mathrm{Eh}, \mathrm{TOC}$, temperature, silt+clay, $\delta^{13} \mathrm{C}$, and $\mathrm{C} / \mathrm{N}$ ratio variables show significant differences at a confidence level of $95 \%$ between dry and rainy seasons.

The data showed normal distribution for the saturated hydrocarbons in the dry season (Table 1) and the rainy season (Table 2).

Table 1 Descriptive statistics of mangroves sediments of Itaparica Island in the dry season

\begin{tabular}{lllllllll}
\hline & Valid $N$ & Mean & G.M. & Median & Min. & Max. & Var. \\
\hline Temp. $\left({ }^{\circ} \mathrm{C}\right)$ & 30 & 31.77 & 31.67 & 32.45 & 27.20 & 35.80 & 6.43 \\
pH & 30 & 7.03 & 7.01 & 7.04 & 5.91 & 8.29 & 0.44 & 2.54 \\
Eh & 30 & 36.33 & 24.18 & 32.50 & 1.00 & 98.00 & 659.50 & 25.68 \\
Sand & 30 & 77.84 & 77.43 & 79.01 & 56.78 & 87.06 & 60.59 & 7.78 \\
Silt+clay & 30 & 22.16 & 20.99 & 20.99 & 12.94 & 43.22 & 60.59 & 7.78 \\
$\delta^{13}$ C & 30 & -18.47 & - & -20.85 & -24.50 & 0.00 & 37.52 \\
TOC & 30 & 0.53 & 0.35 & 0.51 & 0.06 & 1.89 & 0.20 & 6.13 \\
TOC/TN & 28 & 10.67 & 10.21 & 10.00 & 6.00 & 19.00 & 9.06 & 0.44 \\
CPI $_{22-26}$ & 8 & 0.24 & 0.19 & 0.18 & 0.11 & 0.83 & 0.06 \\
CPI $_{26-36}$ & 15 & 0.47 & 0.36 & 0.32 & 0.13 & 1.54 & 0.17 \\
En-Alk & 18 & 0.63 & 0.45 & 0.48 & 0.13 & 2.08 & 0.32 \\
\hline
\end{tabular}

Temp. temperature, TOC total organic carbon, $\Sigma n$-Alk somatory of n-alkanes, G.M. geometric mean, Min minimum, Max maximum, Var variance, $S d$ standard deviation, - not calculated 
Table 2 Descriptive statistics of mangroves sediments of Itaparica Island in the rainy season

\begin{tabular}{|c|c|c|c|c|c|c|c|c|}
\hline & Valid $N$ & Mean & G.M. & Median & Min. & Max. & Var. & Sd. \\
\hline Temp. $\left({ }^{\circ} \mathrm{C}\right)$ & 30 & 29.21 & 29.17 & 29.00 & 26.20 & 32.30 & 2.60 & 1.62 \\
\hline $\mathrm{pH}$ & 30 & 7.42 & 7.36 & 7.440 & 5.40 & 9.42 & 0.79 & 0.89 \\
\hline $\mathrm{Eh}$ & 30 & 37.57 & 23.15 & 29.00 & 1.00 & 117.00 & 990.20 & 31.47 \\
\hline Sand & 30 & 77.84 & 77.43 & 79.01 & 56.78 & 87.06 & 60.59 & 7.78 \\
\hline Silt+clay & 30 & 24.66 & 22.44 & 23.07 & 6.23 & 52.77 & 111.70 & 10.57 \\
\hline$\delta^{13} \mathrm{C}$ & 30 & -19.88 & - & -20.10 & -26.00 & 0.00 & 26.28 & 5.13 \\
\hline TOC & 30 & 0.60 & - & 0.39 & 0.00 & 2.05 & 0.29 & 0.54 \\
\hline $\mathrm{TOC} / \mathrm{TN}$ & 29 & 11.76 & 11.49 & 12.00 & 6.00 & 16.00 & 6.12 & 2.47 \\
\hline $\mathrm{CPI}_{22-26}$ & 8 & 0.30 & 0.25 & 0.20 & 0.13 & 0.77 & 0.05 & 0.22 \\
\hline $\mathrm{CPi}_{26-36}$ & 15 & 0.77 & 0.35 & 0.22 & 0.10 & 5.30 & 1.85 & 1.36 \\
\hline$\sum \mathrm{n}-\mathrm{Alk}$ & 18 & 1.03 & 0.74 & 0.66 & 0.21 & 5.50 & 1.48 & 1.22 \\
\hline
\end{tabular}

Temp. temperature, TOC total organic carbon, $\Sigma n$-Alk somatory of n-alkanes, G.M. geometric mean, Min minimum, Max maximum, Var variance, $S d$ standard deviation, - not calculated

Total organic carbon and total nitrogen ratios and grain size distribution

In the dry season, the content of total organic carbon (TOC, Tables 4 and 5) at all stations that ranged from 0.09 to $0.96 \%$ but reached up to $2.05 \%$ in the rainy season are presented in Tables 1 to 5 . The TOC concentrations in sediment samples from mangroves of Mocambo (1) and Jiribatuba (6) villages were significantly lower in comparison to other stations in the same period.

The amount of total organic carbon in Itaparica Island compared to other countries and studies performed in TSB (Table 3) are lower in this study.

Total nitrogen (TN) values also show a wide range and distribution pattern similar to TOC. The lowest values of TOC and TN are found in the inner relict sands (TOC of 0.9 to $0.5 \%$ ) and higher values on the

Table 3 Comparison of total organic carbon in sediments from different sites

\begin{tabular}{lll}
\hline Local & $\begin{array}{l}\text { Total amount } \\
\text { organic carbon } \\
(\%)\end{array}$ & Reference \\
\hline $\begin{array}{l}\text { Todos os Santos } \\
\text { Bay-BA }\end{array}$ & $2.4-4.18$ & Veiga et al. 2008 \\
$\begin{array}{l}\text { Mandovi-India } \\
\text { Marmugoa-India }\end{array}$ & $\begin{array}{l}0.6-2.5 \\
\text { Dom João-BA }\end{array}$ & Harji et al. 2008 \\
Itaparica Island-BA & $0.09-3.00$ & Celino et al. 2008a, b \\
\hline
\end{tabular}

outer silty clays. Elevated TOC $(>0.75 \%)$ and TN content are found off the river. TOC/TN ratios mostly range between 8 and 14 .

A good relation is seen between the proportion of mud fraction (silt and clay) and TOC content (Fig. 4). Organic matter is known to be associated with finegrained sediments because of the larger surface area which provides good binding sites for organic matter (Meyers 1997). The stations established in Jiribatuba and Mocambo are located in areas with high mobility of sediments caused by tidal movement (Lessa et al. 2008). In addition to the reasons above, the leaching can influence low TOC concentrations for some stations in the rainy season (Table 5). The relict-sand dominated areas have low TOC and TN content.

The range of TOC $(0.09$ to $1 \%)$ on the Itaparica Island is similar to those major rivers in high tidal regimes like Amazon, Changjiang, Pearl River etc (Hu et al. 2009).

Spatial and temporal distribution of saturated hydrocarbons

As a result, for comparison in the different regions sampled in this study, hydrocarbons results (Tables 4 and 5) investigated were expressed related to the dry sediment. Moreover, the n-alkane profile distribution (n-Alk) derived from biogenic and different petrogenic sources exhibit distinct typical pattern which can be evaluated by the so-called Preferred Carbon Index (CPI). The CPI is a dimensionless quantity that relates 
Table 4 Median of physico-chemical parameters, pH, Eh, silt+clay, $\delta^{13} \mathrm{C}$, TOC, TOC/TN, CPI, CPI $16-20, \mathrm{CPI}_{22-26}, \mathrm{CPI}_{26-36}$, and $\Sigma \mathrm{n}-$ Alk the mangroves surface sediments of Itaparica Island, Bahia in the dry season

\begin{tabular}{lllllllllllll}
\hline Site & T $\left({ }^{\circ} \mathrm{C}\right)$ & $\mathrm{pH}$ & $\mathrm{Eh}$ & Silt+clay & $\delta^{13} \mathrm{C}$ & $\mathrm{TOC}$ & $\mathrm{TOC} / \mathrm{TN}$ & $\mathrm{CPI}$ & $\mathrm{CPI}_{16-20}$ & CPI $_{22-26}$ & $\mathrm{CPI}_{26-36}$ & $\Sigma \mathrm{n}-\mathrm{Alk}$ \\
\hline 1 & 34.8 & 6.48 & 52 & 24.0 & -14.4 & 0.09 & 8.4 & - & - & - & - & 0.08 \\
2 & 32.8 & 6.88 & 31 & 21.0 & -21.8 & 0.96 & 12.2 & - & - & 0.16 & 0.37 \\
3 & 32.4 & 7.22 & -19 & 16.0 & -20.1 & 0.58 & 12 & 1.2 & - & 0.14 & 0.31 & 0.74 \\
4 & n.d. & n.d. & n.d. & 7.0 & -16.5 & 0.21 & 9.7 & 1.5 & 0.52 & 2.9 & 0.13 & 0.56 \\
5 & n.d. & n.d. & n.d. & 18.0 & -23.7 & 0.41 & 14.3 & 2.7 & - & 0.38 & 0.34 & 0.33 \\
6 & 28.3 & 6.34 & 63 & 20.0 & -15.2 & 0.16 & 8 & - & - & - & 0.14 & 0.24 \\
7 & 30.6 & 7.24 & 11 & 25.0 & -23.4 & 0.50 & 11.5 & - & 0.65 & 0.18 & 0.47 & 1.01 \\
\hline
\end{tabular}

n.d. not determined, - not calculated

the amounts of n-Alk series of odd and even carbon number. The value of this index indicates the predominance of hydrocarbons of these series which helps to infer that the n-Alk amount of n-Alk with odd number of carbon is dominant in its structure. This indicates a predominance biogenic for these compounds. When the CPI is less than unity the predominant n-Alk is the number of even carbons whose dominant source indicated is anthropogenic (Aboul-Kassim and Simoneit, 1996). However, if the CPI is equal or very close to unity an indication of its origin is petrogenic but should not be used isolatedly.

The spatial distribution of hydrocarbons in sediments of mangrove swamps of Itaparica Island-BA studied by comparing the concentrations of n-Alk among different sampling sites (Mocambo, Misericordia, Baiacu, Ponta Grossa, Campinas, Jiribatuba, and Cacha Prego) during dry and rainy seasons.

Looking at Fig. 2, concentrations of n-Alk were found above $2 \mu \mathrm{g} \mathrm{g}^{-1}$ dry sediment in BI4 and PG1 during dry season and CP2 and CP4 in the rainy season.
Concentrations found in the village of Mocambo were below LQM $\left(0.10 \mu \mathrm{g} \mathrm{g}^{-1}\right.$ dry sediment $)$ in the dry season. The other locations are plenty of high molecular weight $n$-alkanes $\left(>n \mathrm{C}_{20}\right)$, both in dry and in wet seasons. Carbon chain length in the range $n \mathrm{C}_{23} n_{\mathrm{C}_{35}}$ is characteristic of $n$-alkanes source land derived wax cuticle from vascular plants, depending on the local vegetation it can predominantly occur $n \mathrm{C}_{25}, n \mathrm{C}_{27}$, and $n \mathrm{C}_{29}$, $n \mathrm{C}_{31}$ (Veiga et al. 2008).

During the dry MD, BI and CA showed a mixture of organic matter of algal debris and vegetation due to predominant continental $\mathrm{CPI}_{22-26}$ and $\mathrm{CPI}_{26-36}$ (Table 4) (Commendatore et al. 2000; Stout et al. 2001). $\mathrm{PG}$ and $\mathrm{CP}$ also present predominance $\mathrm{CPI}_{22}$ 26 and $\mathrm{CPI}_{26-36}$ is the presence of $\mathrm{CPI}_{16-20}$ due to phytoplankton and bacteria (Commendatore et al. 2000). JI organic matter presents continental vegetation due to predominant $\mathrm{CPI}_{26-36}$ (Stout et al. 2001). In the rainy season $\mathrm{MD}, \mathrm{BI}$ and $\mathrm{PG}$ also present predominance in $\mathrm{CPI}_{22-26}$ and $\mathrm{CPI}_{26-36}$ is the presence of $\mathrm{CPI}_{16-20}$ due to phytoplankton and bacteria in

Table 5 Median physico-chemical parameters, pH, Eh, silt+clay, $\delta^{13} \mathrm{C}$, TOC, TOC/TN, CPI, CPI $16-20, \mathrm{CPI}_{22-26}, \mathrm{CPI}_{26-36}$, and $\Sigma \mathrm{n}-A \mathrm{lk}$ the mangroves surface sediments of Itaparica Island, Bahia in the rainy season

\begin{tabular}{lllllllllllll}
\hline Site & $\mathrm{T}\left({ }^{\circ} \mathrm{C}\right)$ & $\mathrm{pH}$ & $\mathrm{Eh}$ & Silt+clay & $\delta^{13} \mathrm{C}$ & $\mathrm{TOC}$ & $\mathrm{TOC} / \mathrm{TN}$ & $\mathrm{CPI}$ & $\mathrm{CPI}_{16-20}$ & $\mathrm{CPI}_{22-26}$ & $\mathrm{CPI}_{26-36}$ & $\Sigma \mathrm{n}-\mathrm{Alk}$ \\
\hline 1 & 27.3 & 7.88 & -27 & 19.0 & -15.6 & 0.19 & 9.1 & - & - & - & - & 0.08 \\
2 & 28.2 & 7.32 & 10 & 24.5 & -22.9 & 1.42 & 12.8 & - & - & 0.16 & 0.37 \\
3 & 30.6 & 7.18 & -15 & 15.5 & -19.7 & 0.35 & 10.8 & 1.2 & - & 0.14 & 0.31 & 0.74 \\
4 & 27.8 & 6.58 & 49 & 14.0 & -21.8 & 2.05 & 10.9 & 1.5 & 0.52 & 2.90 & 0.13 & 0.56 \\
5 & 30.0 & 6.43 & 59 & 14.0 & -20.3 & 0.08 & 11.7 & 2.7 & - & 0.38 & 0.34 & 0.33 \\
6 & 28.7 & 7.49 & 5.0 & 35.5 & -18.4 & 0.26 & 10.5 & - & - & - & 0.14 & 0.24 \\
7 & 31.1 & 6.38 & 62 & 27.5 & -25.5 & 0.81 & 14.8 & - & 0.65 & 0.18 & 0.47 & 1.01 \\
\hline
\end{tabular}

n.d. not determined, - not calculated 


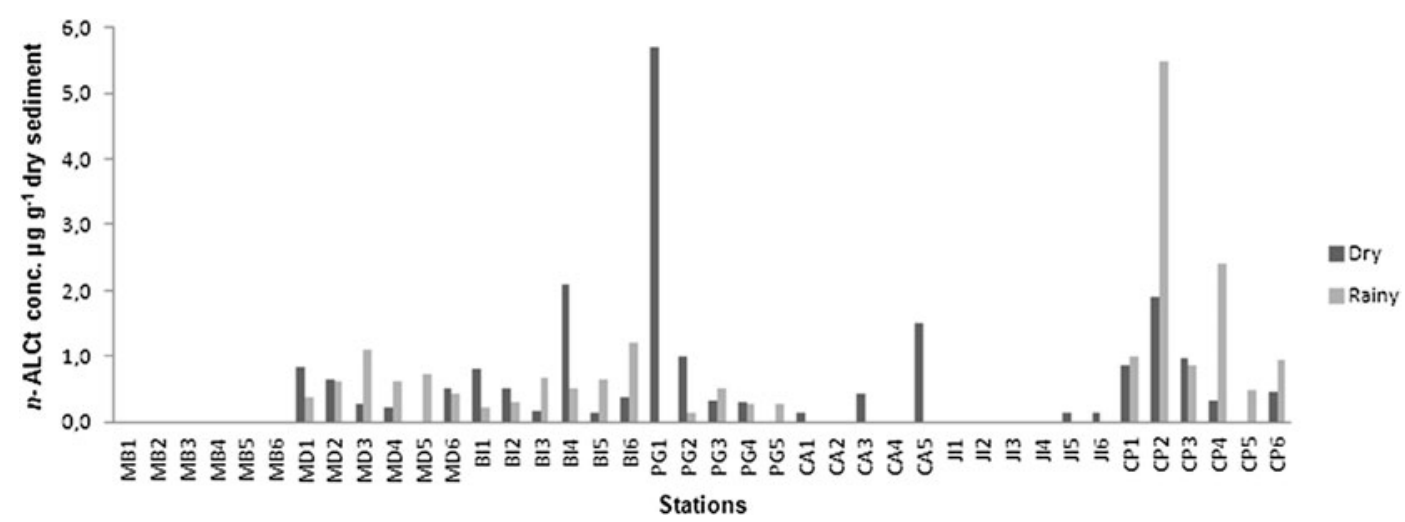

Fig. 2 Distribution of $\sum$ n-alk in surface sediments of the Itaparica Island-BA

Table 5 (Commendatore et al. 2000). CP showed a mixture of organic matter of algal debris and vegetation due to predominant continental $\mathrm{CPI}_{22-26}$ and $\mathrm{CPI}_{26-36}$ in Table 5 (Commendatore et al. 2000; Stout et al. 2001).
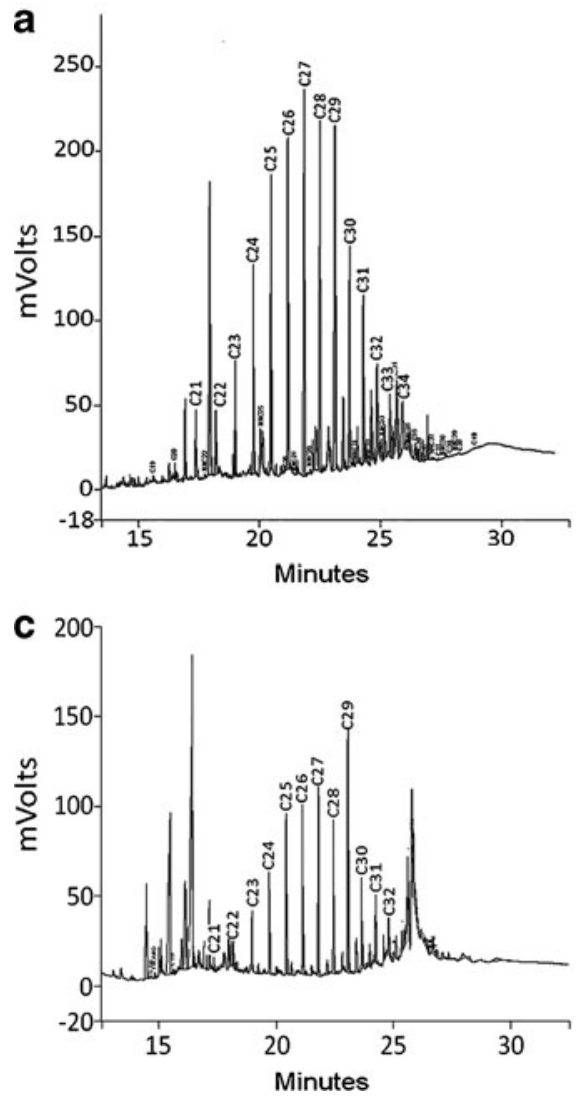

Fig. 3 Chromatograms showing the distribution of n-alkanes of the dry period: a BI4 Station BI, in the village of Baiacu, b PG1 PG station in the village of Ponta Grossa, c CA3 station CA in
In the rainy season, the JI (Fig. 5) maximum concentration values in $n \mathrm{C}_{27}$ are predominantly observed. n-alkanes of high molecular weight abound $\left(>n \mathrm{C}_{20}\right)$, in which the concentration of odd over the even ones is predominantly typical of higher plants (mangrove)

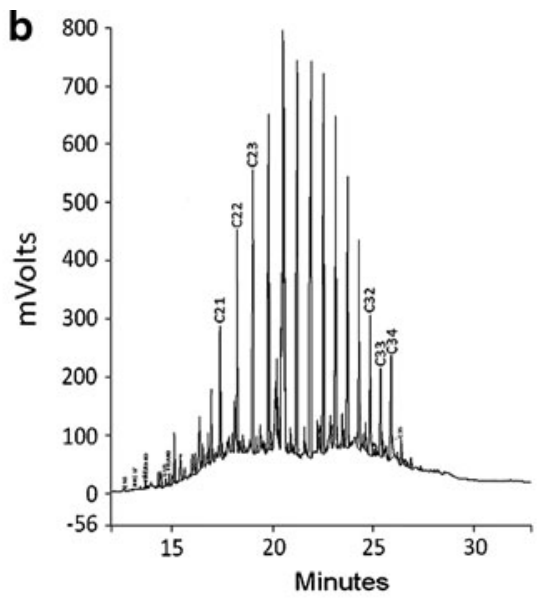

d

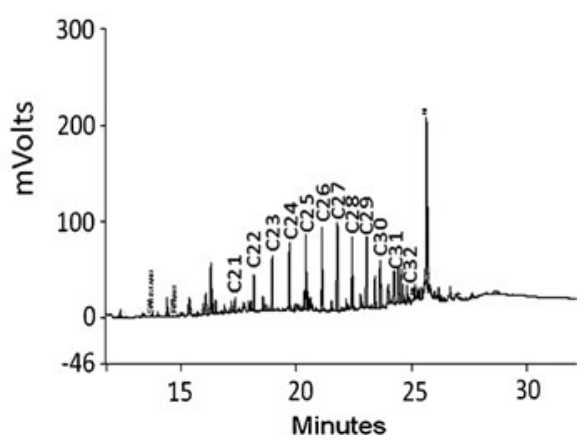

the town of Campinas and JI5 in JI station during rainy season in the village of Jiribatuba in Itaparica Island-BA 
Fig. $4 \%$ TN versus \% TOC the dry period (a) and rainy season (b) in sediments of the Island Itaparica, Bahia, Brazil
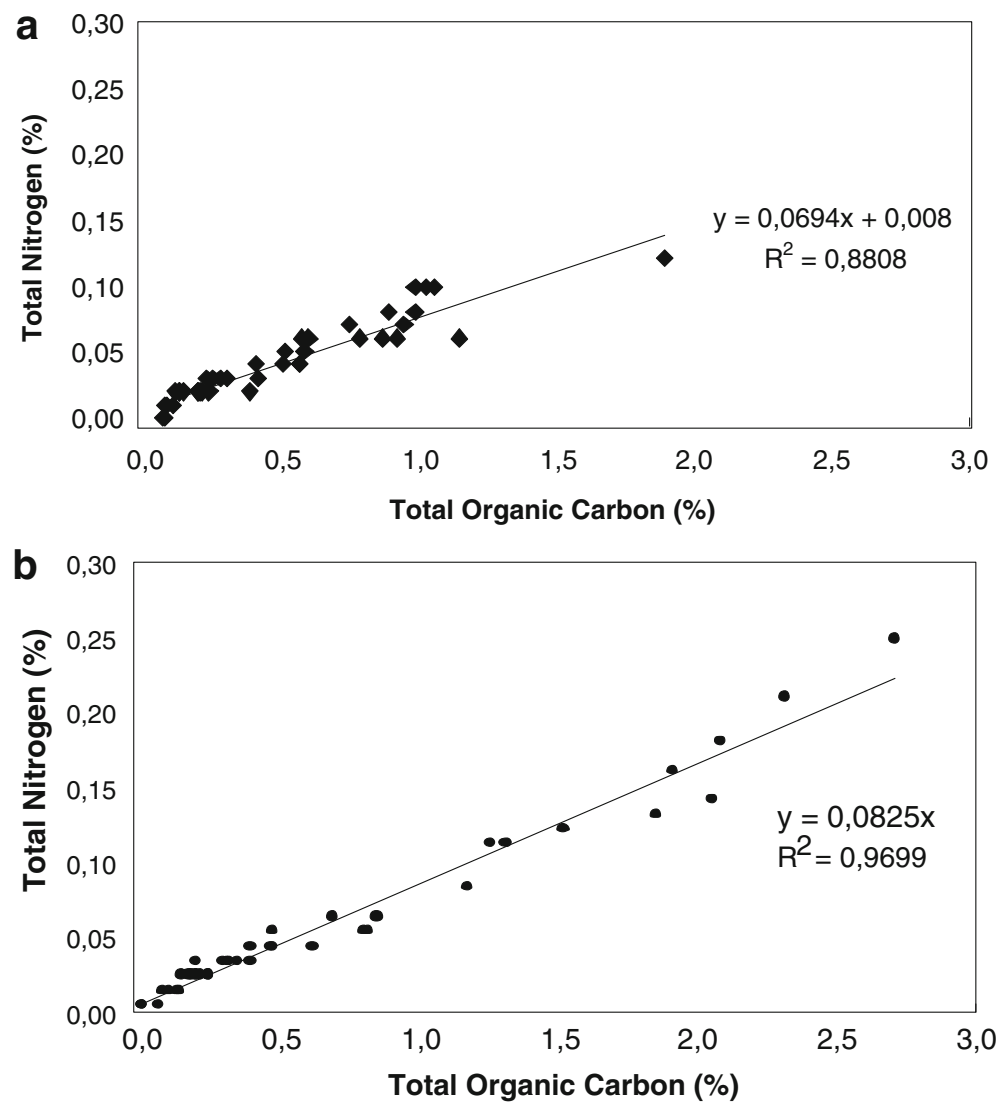

(Le Dréau et al. 1997), evidenced by $n \mathrm{C}_{25}$ and $n \mathrm{C}_{29}$ that exhibit maximum peak concentrations. The chromatogram shows a typical profile of a mixture of contribution of organic matter illustrated by the marked depletion of the compounds $n \mathrm{C}_{21}, n \mathrm{C}_{22}, n \mathrm{C}_{31}$, and $n \mathrm{C}_{32}$, suggesting a mixing source with strong oil influence (Fig. 3).

One side of Itaparica Island faces the Atlantic Ocean and the other one faces the TSB, where there are the mangroves of Misericordia, Baiacu, Ponta Grossa, Campinas, and Jiribatuba. This side works as a source of protection due to the influence of ocean currents bringing the hydrocarbons into the TSB (Lessa et al. 2008).

The establishment of contamination levels by hydrocarbons is related to their concentration in the environment. In harbor areas, industrial and urban petrogenic hydrocarbons may have concentration between 10 and $1,000 \mu \mathrm{g} \mathrm{g}^{-1}$ dry sediment (UNEP, 1992). Some studies were carried in TSB, such as Wagener et al. (2010), who studied TSB sediments and found concentration ranging from 0.47 to $18.69 \mu \mathrm{g} \mathrm{g}^{-1}$ dry sediment. Celino et al. (2008a, b) studied the Northern TSB and found concentration ranging from 1.0 to $5.7 \mathrm{\mu g} \mathrm{g}^{-1}$ dry sediment. In the present study the concentration was between 0.14 and $5.7 \mu \mathrm{g} \mathrm{g}^{-1}$ dry sediment in the dry season and 0.21 to $5.5 \mu \mathrm{g} \mathrm{g}^{-1}$ dry sediment during the rainy season, implying that the contamination found in Itaparica Island is lower when compared to studies in TSB (Fig. 4).

Sources of organic matter

TOC/TN ratio has been used to identify the source of organic matter. Some authors have suggested different values of TOC/TN ratio, according to the source of organic matter. Saito et al. (1989) suggested ratio greater than 20 to ground source and 5 to 7 as marine source. Additionally, Stein (1991) recorded values below 10, what suggests marine origin and values around 10 are components of both marine and terrestrial sediment.

In this study the TOC/TN ratio ranged from 8 to 14.3 in the dry season (Table 4) and from 9.1 to 14.8 in the rainy season (Table 5). Analyzing TOC/TN values 
Fig. 5 a Graphic scores for the dry season regarding the variables of mangroves surface sediment samples in Itaparica Island, Bahia, Brazil. b Weights chart for the dry season of mangrove surface sediment samples of Itaparica Island, Bahia, Brazil
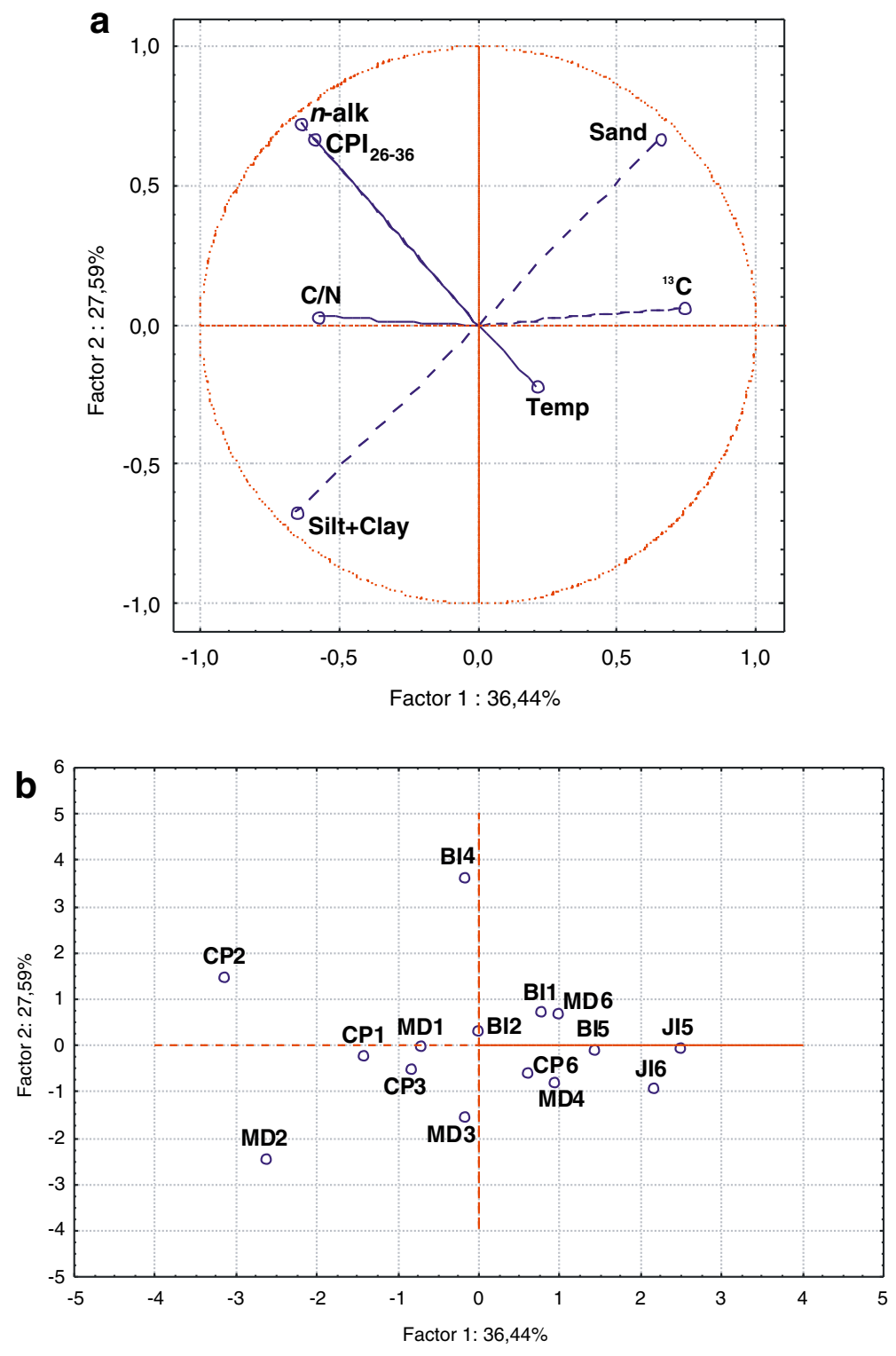

in surface sediments in the dry season for MB5, the MD1 MD6, BI1, BI2, BI5, PG1, PG3, PG4, MP5, CA1, CA3, CA4, CA5, J11, CP1, CP2, CP3, and CP4 indicated a mixture of organic matter origin in marineterrestrial, except for the MB2, MB4, MB6, Bi3, BI4, BI6, PG2, and CA2, the J12, JI6, CP5, and CP6, whose origin is marine. MB2 in the rainy season, the MD1 MD6, BI1, Bi3, BI5, BI6, and PG2, the MP5, CA3, CA5, JI1, J12, JI3, JI6, and CP1 to CP6 showed a mixture of marine-terrestrial organic matter origin except for MB1, MB3, MB5, MB6, BI2, BI4, PG1, CA1, JI4, and JI5 which presented marine origin.
Low TOC/TN ratios have been ascribed to higher portion of soil-derived organic carbon $(\mathrm{Hu}$ et al. 2009).

The stable carbon isotopic composition $\left(\delta^{13} \mathrm{C}\right)$ has also been used to distinguish the organic matter, either from marine sources or terrestrial plants sources (Schubert and Calvert 2001). Marine organic matter typically has $\delta^{13} \mathrm{C}$ values ranging from -19 to $-21 \%$. Terrestrial plants with $\mathrm{C}_{3}$ have an average value of $\delta^{13} \mathrm{C}-27 \%$ ( -22 and $-33 \%$ ), while for $\mathrm{C} 4$ it varies from -9 to $-16 \%$, with an average $-13 \%$ o $(\mathrm{Hu}$ et al. 2009). Most oils show $\delta^{13} \mathrm{C}$ values in the range of -21 
to $-32 \%$. The frequency distribution shows a strong peak between -28 and $-29 \%$ (Mook and Vries 2001).

The $\delta^{13} \mathrm{C}$ in the present study ranged from -14.4 to $-23.7 \%$ (Table 5) during the dry season and -1 and $\mathrm{TOC} / \mathrm{TN}$ ratio has been used to 5.6 to $-25.5 \%$ during the wet season, suggesting a mixture of marine/land source to organic matter. From MD, CA and CP in the dry season, one can infer that the oil presence results from $\delta^{13} \mathrm{C}-21.8,-23.7$, and $-23.4 \%$, respectively. In the rainy season $\mathrm{MD}, \mathrm{CP}$ and $\mathrm{PG}$ showed traces of oil $\delta^{13} \mathrm{C}-22,-25.5$, and $-21.8 \%$, respectively. For both periods the isotopic composition range approaches the terrestrial plants range due to oil isotopic composition being considered lighter than sea carbonates (Mook and Vries 2001).

In order to verify the behavior of saturated hydrocarbons over the dry and rainy seasons it was used PCA, using 7.0 Statistica program made from preprocessed and normalized data through selfscheduling. The significance assessment occurred by ANOVA: single factor at $95 \%$ confidence.

For dry season a data set with seven variables and 15 samples was made. PC1 and PC2 explained $64.03 \%$ of the total variance. Figure 5 is observed in
Fig. 6 a Graphic scores for the variables of mangroves surface sediments samples of Itaparica Island, Bahia, Brazil. b Chart weights of the rainy season for the points of mangroves surface sediments samples of mangroves of Itaparica Island, Bahia, Brazil
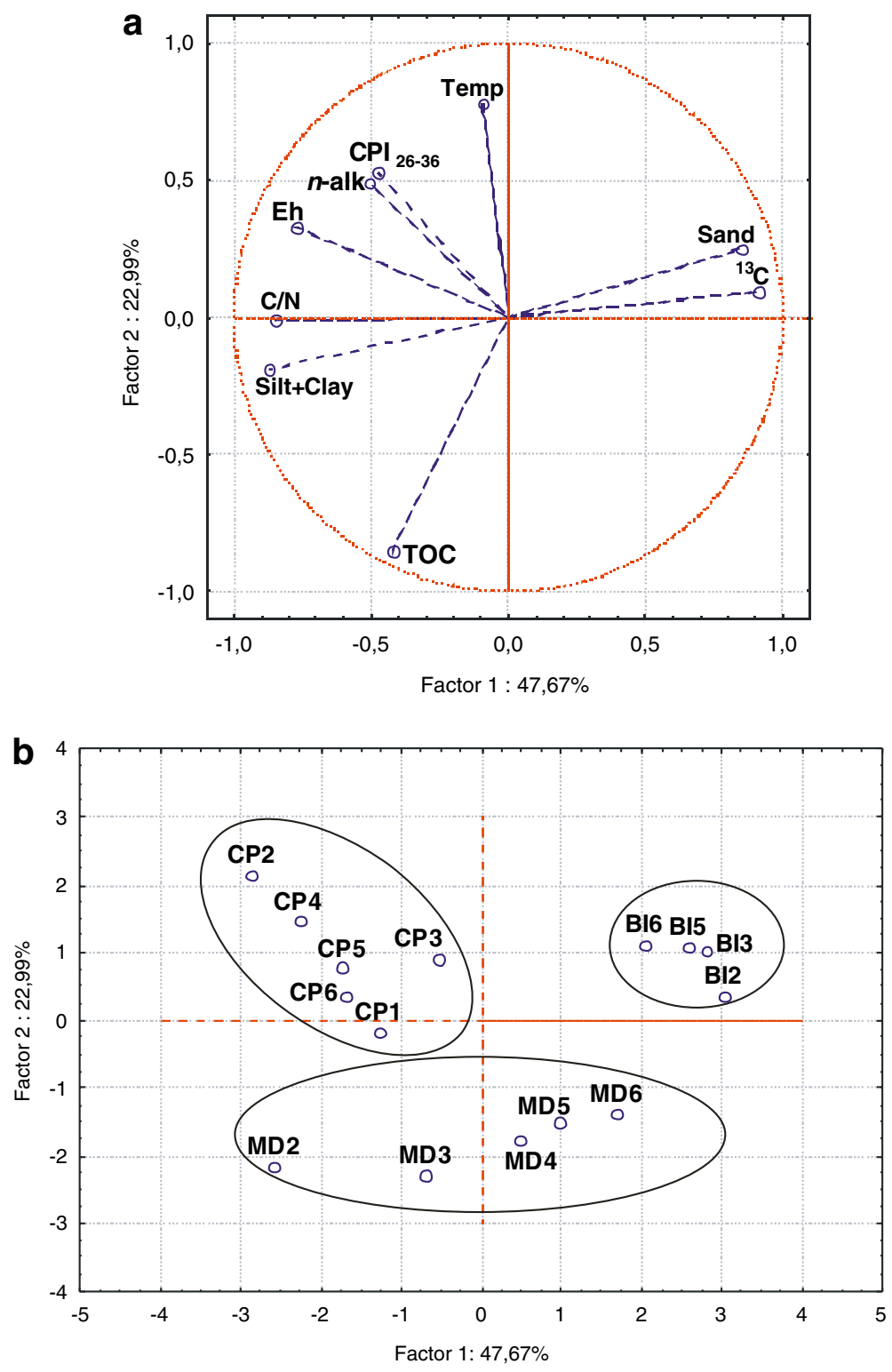
PC2 positive correlations between sand, $\mathrm{CPI}_{26-36}$ and $n$-Alk contributing to the classification of $\mathrm{CP} 2$ and BI4 (Fig. 5). The $\delta^{13} \mathrm{C}$ (Fig. 5) contributes to JI5 classification (Fig. 5). There was a negative correlation for PC2 regarding silt+clay ratio (Fig. 5) contributing to MD2 (Fig. 5), temperature (Fig. 5) for MD4, JI6 and CP6 classification (Fig. 5).

In the rainy season, a set of data samples 9 and 15 variables was made. PC1 and PC2 explained $70.66 \%$ of the total variance. Figure 6 is observed in PC2positive correlations among temperature, $\mathrm{CPI}_{26-36}$, $\sum \mathrm{n}$-alk, and Eh, contributing to the formation of an assembly made by CP1, CP2, CP3, CP4, CP5, and CP6 (Fig. 6). $\delta^{13} \mathrm{C}$ and sand (Fig. 6) contribute to the formation of an assembly made by $\mathrm{BI} 2, \mathrm{BI} 3, \mathrm{BI} 5$, and BI6 (Fig. 6). Negative correlation is observed in PC2 for silt+clay and TOC (Fig. 6) contribute to the formation of an assembly made by MD2, MD3, MD4, MD5, and MD6 (Fig. 6).

No statistically significant correlation was found between TOC and $\Sigma$ n-alk. Regarding plants derived from n-alkanes, this can be expected due to n-alkanes differential degradation and some carbon and organic material fractions from lignins and humic matter (Wagener et al. 2010).

\section{Conclusion}

Organic matter content correlates well with grain size and comparatively higher organic matter content is present fine-grained inner sediments and lower organic in the outer relict sands. Comparatively low rates of processing of soil carbon from source region floodplains and rapid burial on the shelf leads to better preservation of terrestrial carbon in the continental shelf sediments (Ramaswamy et al. 2008).

Although mangroves have presented a mixture of hydrocarbon sources, from terrestrial and marine origin, both TOC/TN ratio and stable carbon isotopic composition $\left(\delta^{13} \mathrm{C}\right)$, indication of oil presence was found through the chromatographic profiles for BI4, $\mathrm{C} 3$, and PG1 during dry season and JI5 during rainy season, as well as $\delta^{13} \mathrm{C}$ which presented information about the presence of oil in Misericordia and Cacha Prego during dry and rainy season, in Campinas during dry season, and Ponta Grossa in the rainy season. The concentrations of $\Sigma$ n-alk were between 0.14 and $5.7 \mu \mathrm{g} \mathrm{g}^{-1}$ dry sediment in the dry season and 0.21 to
$5.5 \mu \mathrm{g} \mathrm{g}^{-1}$ dry sediment in the rainy season, implying that the contamination found in Itaparica Island is lower when compared with studies in TSB.

\section{References}

Aboul-Kassim, T. A. T., \& Simoneit, B. R. T. (1996). Lipid geochemistry of surficial sediments from the coastal environment of Egypt. I. Aliphatic hydrocarbons - characterization and sources. Marine Chemistry, 54, 135-158.

Banjoo, D. R., \& Nelson, P. K. (2005). Improved ultrasonic extraction procedure for the determination of polycyclic aromatic hydrocarbons in sediments. Journal of Chromatography, 1066, 9-18.

Berrêdo, J. F., Costa, M. L., \& Progene, M. P. S. (2008). Efeitos das variações sazonais do clima tropical úmido sobre as águas e sedimentos de manguezais do estuário do rio Marapanim, costa nordeste do Estado do Pará. Acta Amazonia, 38(3), 473-482.

Bordovsky, O. K. (1965). Accumulation of organic matter in bottom sediments. Marine Geology, 3, 33-82.

Burone, L., Muniz, P., Pires-Vanin, A. M. S., \& Rodrigues, M. (2003). Spatial distribution of organic matter in the surface sediments of Ubatuba Bay (Southeastern-Brazil). Annals of the Brazilian Academy of Sciences, 75(1), 77-90.

Celino, J. J., \& Queiroz, A. F. S. (2006). Fonte e grau da contaminação por hidrocarbonetos policíclicos aromáticos (HPAs) de baixa massa molecular em sedimentos da baía de Todos os Santos. Bahia. R. Esc. Minas, 59(3), 265-270.

Celino, J. J., Triguis, J. A., Veiga, I. G., \& Queiroz, A. F. S. (2008a). Assessment of contamination by trace metals and petroleum hydrocarbons in sediments from the tropical estuary of Todos os Santos Bay, Brazil. Revista Brasileira de Geociências, 38(4), 186-196.

Celino, J. J., Triguis, J. A., Veiga, I. G., \& Queiroz, A. F. S. (2008b). Fonte e distribuição de hidrocarbonetos do petróleo nos sedimentos da Baía de Todos os Santos, Bahia. Journal Aquatic Science and Tecnology, 12(1), 31-38.

Celino, J. J., Corseuil, H. X., Fernandes, M., \& Hadlich, G. M. (2012). Persistent toxic substances in surface water of Todos Os Santos Bay, Brazil. Resources and Environment, 2, 141-149.

Commendatore, M. G., Esteves, J. L., \& Colombo, J. C. (2000). Hydrocarbons in coastal sediments of Patagonia, Argentina: levels and probable sources. Marine Pollution Bulletin, 40(11), 989-998.

Costa, A. B., Novotny, E. H., Bloise, A. C., de Azevedo, E. R., Bonagamba, T. J., Zucchi, M. R., Santos, V. L. C. S., \& Azevedo, A. E. G. (2011). Characterization of organic matter in sediment cores of the Todos os Santos Bay, Bahia, Brazil, by elemental analysis and ${ }^{13} \mathrm{C}$ NMR. Marine Pollution Bulletin, 62, 1883-1890.

Ekpo, B. O., Oyo-Ita, O. E., \& Oros, D. R. (2012). Distributions and sources of polycyclic aromatic hydrocarbons in surface sediments from the Cross River estuary, SE Niger Delta, Nigeria. Environmental Monitoring And Assessment, 184, 1037-1047. 
EMBRAPA, Empresa Brasileira de Pesquisa Agropecuária, 1999. Manual de análises químicas de solos, plantas e fertilizantes. Brasil.

Gonsalves, M. J., Fernandes, C. E. G., \& Fernandes, S. O. (2011). Effects of composition of labile organic matter on biogenic production of methane in the coastal sediments of the Arabian Sea. Environmental Monitoring And Assessment, 182, 385-395.

Harji, R. R., Yvenat, A., \& Bhosle, N. B. (2008). Sources of hydrocarbons in sediments of the Mandovi estuary and the Marmugoa harbour, west coast of India. Environment International, 34, 959-965.

Hu, L., Guo, Z., Feng, J., Yang, Z., \& Fang, M. (2009). Distributions and sources of bulk organic matter and aliphatic hydrocarbons in surface sediments of the Bohai Sea, China. Marine Chemistry, 113, 197-211.

Killops, S., \& Killops, V. (2005). Introduction to organic geochemistry. USA: Blackwell.

Le Dréau, Y., Jacquot, F., Doumenq, P., Guiliano, M., Bertrand, J. C., \& Mille, G. (1997). Hydrocarbon balance of site which had been highly and chronically contaminated by petroleum wastes of a refinery (from 1956 to 1992). Marine Pollution Bulletin, 34(6), 456-468.

Lessa, G. C., Cirano, M., Genz, F., Tanajura, C. A. S., \& da Silva, R. R. (2008). Oceanografia física. In Baía de Todos os Santos (pp. 71-119). Salvador: EDUFBA.

Magalhães, D., Bruns, R. E., \& Vasconcellos, P. C. (2007). Hidrocarbonetos policíclicos aromáticos como traçadores da queima de cana-de-açucar: uma abordagem estatística. Química Nova, 30(3), 577-581.

Mahiques, M. M., Mishima, Y., \& Rodrigues, M. (1999). Characteristics of the sedimentary organic matter on the inner and middle continental shelf between Guanabara Bay and São Francisco do Sul, southeastern Brazilian margin. Continental Shelf Research, 19, 775-798.

McGroddy, S. E., \& Farrington, J. W. (1995). Sediment porewater partitioning of polycyclic aromatic hydrocarbons in three cores from Boston Harbor Massachusetts. Environment Science Technology, 29, 1542-1550.

Meyers, P. A. (1997). Organic geochemical proxies of paleoceanography, paleolimnologic and paleoclimatic processes. Organic Geochemistry, 27, 213-250.

Moldowan, M., Walters, C. C., \& Peters, K. E. (2007). The biomarker guide: biomarkers and isotopes in petroleum exploration and earth history. Cambridge: Nova York.

Mook, W. G., \& Vries, J. J. (2001). Environmental isotopes in the hydrological cycle: principles and applications. Vienna: International Agency of Atomic Energy.

Pait, A. S., Whitall, D. R., \& Dieppa, A. (2012). Characterization of organic chemical contaminants in sediments from Jobos Bay, Puerto Rico. Environmental Monitoring And Assessment, 184, 5065-5075.

Praveena, S. M., Kwan, O. W., \& Aris, A. Z. (2012). Effect of data pre-treatment procedures on principal component analysis: a case study for mangrove surface sediment datasets. Environmental Monitoring And Assessment, 184, 6855-6868.
Queiroz, A. F. S., \& Celino, J. J. (2008). Avaliação de ambientes na Baía de Todos os Santos: aspectos geoquímicos, geofisicos e biológicos. Salvador: EDUFBA.

Ramaswamy, V., Gaye, B., Shirodkar, P. V., Rao, P. S., Chivas, A. R., Wheeler, D., \& Thwin, S. (2008). Distribution and sources of organic carbon, nitrogen and their isotopic signatures in sediments from the Ayeyarwady (Irrawaddy) continental shelf, northern Andaman Sea. Marine Chemistry, 111, 137-150.

Readman, J. W., Fillmann, G., Tolosa, I., Bartocci, J., Villeneuve, J. P., Catinni, C., \& Mee, L. D. (2002). Petroleum and PAH contamination of the Black Sea. Marine Pollution Bulletin, 44, 48-62.

Rossi, M., \& Mattos, I. F. A. (2002). Solos de mangue do Estado de São Paulo: caracterização química e física. Revista do departamento de Geografia, 15, 101-113.

Saito, Y., Nishimura, A., \& Matsumoto, E. (1989). Transgressive sand sheet covering the shelf and upper slope off Sendai, Northeast Japan. Marine Geology, 89, 245-258.

Schubert, C. J., \& Calvert, S. E. (2001). Nitrogen and carbon isotopic composition of marine and terrestrial organic matter in Arctic Ocean sediments: implications for nutrient utilization and organic matter composition. Deep-Sea Research, 48, 789-810.

Souza, M. M., Windmöller, C. C., \& Hatje, V. (2011). Shell fish from Todos os Santos Bay, Bahia, Brazil: treat or threat? Marine Pollution Bulletin, 62, 2254-2263.

StatSoft Inc. (1997). STATISTICA for the windows operating system. Release 7. Tulsa, EUA, Statsoft, Inc.

Stein, R. (1991). Accumulation of organic carbon in marine sediments. Results from the Deep Sea Drilling Project/ Ocean Drilling Program. Berlin: Springer.

Stout, S. A., Uhler, R. M., \& McCarthy, K. J. (2001). A strategy and methodology for defensibly correlating spilled oil to source candidates. Environmental Forensics, 2, 87-98.

UNEP, United Nations Environment Programme, 1992. Determination of petroleum of hydrocarbons in sediments. 20.

Veiga, I. G., Triguis, J. A., Celino, J. J., \& Oliveira, O. M. C. (2008). Hidrocarbonetos saturados em sedimentos de manguezais na área norte da Baía de Todos os Santos. In Queiroz \& Celino (Eds.), Avaliação de ambientes na Baía de Todos os Santos: aspectos geoquímicos, geofísicos e biológicos (pp. 149-172). Salvador: EDUFBA.

Venturini, N., Tommasi, L. R., Bícego, M. C., \& Martins, C. C. (2004). Characterization of the benthic environment of a coastal area adjacent to an oil refinery, Todos os Santos Bay (NEBrazil). Brazilian Journal of Oceanography, 52(2), 123-134.

Volkman, J. K., Holdsworth, D. G., Neill, G. P., \& Bavor, H. J., Jr. (1992). Identification of natural, anthropogenic and petroleum hydrocarbons in aquatic sediments. Science of the Total Environment, 112, 203-219.

Wagener, A., Hamacher, C., Farias, C., Godoy, J. M., \& Scofield, A. (2010). Evaluation of tools to identify hydrocarbon sources in recent and historical sediments of a tropical bay. Marine Chemistry, 121, 67-79.

Zagatto, P. A., \& Bertoletti, E. (2008). Ecotoxicologia Aquática: princípios e aplicações. São Paulo: Rima. 